\title{
Analysis of American Plaice, Cod and Yellowtail Flounder Catches in Research Vessel Surveys on the Tail of the Grand Bank, 1971-89
}

\author{
W. B. Brodie \\ Science Branch, Department of Fisheries and Oceans \\ P. O. Box 5667, St. John's, Newfoundland, Canada A1C 5X1
}

\begin{abstract}
Catches of American plaice (Hippoglossoides platessoides), yellowtail flounder (Limanda ferruginea) and cod (Gadus morhua) were examined from stratified-random research vessel surveys on the Tail of the Grand Bank from 1971 to 1989 to determine the relative proportion of these species present within and outside the Canadian 200-mile fishing boundary. For American plaice and yellowtail flounder, the relative abundance on either side of the 200-mile boundary changed as commercial catches increased outside 200 miles in the mid-1980s. For cod, the relative changes in abundance coincided with the declaration of the 200-mile boundary in 1977 and the subsequent restrictions placed on non-Canadian fisheries. Line transect surveys designed to further examine the spatial distribution of these species were conducted in 1986 and 1987. Larger catches were noted of all three species in most areas inside the 200-mile boundary compared to areas outside 200 miles. Comparison of these results with those from the stratified-random surveys indicated that these proportions of relative abundance were not always present.
\end{abstract}

\section{Introduction}

On 1 January 1977, Canada declared a 200mile fishing boundary around its coastline in order to control the exploitation of resources on the continental shelf. Prior to 1977, catches of fish by nonCanadian vessels had been at very high levels off Canada's east coast. The severe restrictions placed on entry of non-Canadian vessels into this zone brought on by the introduction of the 200-mile boundary (Fig. 1) caused a substantial decrease in these catch levels (ICNAF, 1972-78; NAFO, 1984), however, some fishing continued on the grounds outside the 200-miles in the areas of the Grand Bank known as the Nose (in Div. 3L) and the Tail (in Div. $3 \mathrm{NO}$ ). Although the catches of some species, notably yellowtail flounder (Limanda ferruginea) and American plaice (Hippoglossoides platessoides), by non-Canadian vessels not licensed to fish inside the 200-mile boundary remained low from 1977 through to the early-1980s, they increased sharply from 1983 to 1986 (Brodie and Bowering, MS 1989, Brodie et al., MS 1989). In 1986, many Canadian trawler captains (pers. comm.) reported that the catch rates for flatfish were noticeably lower outside the 200-mile boundary on the Tail of the Bank than inside, with differences being obvious over very short distances. In addition to the two flatfish species, cod (Gadus morhua) also comprised a major component of the groundfish catches on the Tail of the Bank. However, very little information has been published on the distribution of cod, American plaice and yellowtail flounder on the Grand Bank.
The purpose of this study was to determine if significant differences existed in recent years in the abundance of yellowtail flounder, American plaice and cod in the areas on the southern Grand Bank separated by the 200-mile boundary. The study also attempted to relate the patterns of abundance and distribution observed in 1986 and 1987 to those observed from 1971 to 1989 and attempted to determine if perceived differences can be related to the establishment of the 200-mile boundary and the recent increase in fishing effort in the area outside the boundary.

\section{Materials and Methods}

All data analyzed were collected by Canadian research vessels over the periods 1971-82 and 1984-89. For comparison of recent survey results with historic distribution patterns, the surveys on the Tail of the Bank from 1971 to 1989 were examined as follows:

\section{Line transect surveys, April 1986 and March 1987}

To determine the distribution and abundance of groundfish species in the area of the Grand Bank surrounding the 200-mile boundary in NAFO Div. 3N and 30 , line transect surveys were conducted by the research vessels Wilfred Templeman from 1 to 10 April, 1986 (Fig. 2A), and Lady Hammond from 6 to 18 March 1987 (Fig. 2B). Both vessels were large stern trawlers outfitted with a bottom otter trawl lined with small mesh in the codend; the former used an Engels 145 otter trawl while the latter used 


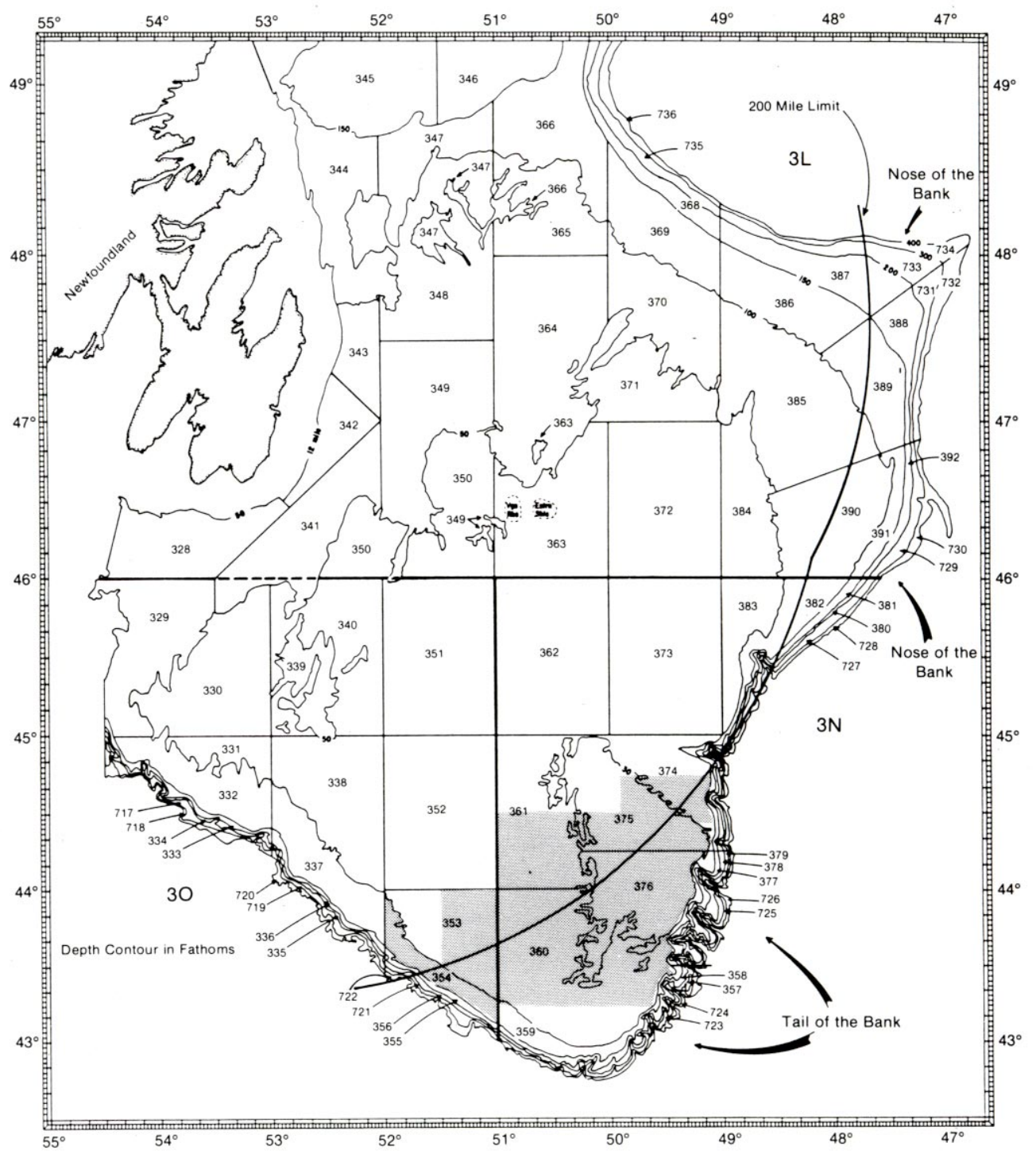

Fig. 1. Map of the Grand Banks (NAFO Div. 3LNO) showing the Canadian 200-mile fishing boundary, the stratification scheme used in the groundfish surveys, and the area chosen (shaded) for comparison of survey catches.

a Western 2A trawl. These two vessel-gear combinations differed in the fishing power, so comparisons of catch sizes between years were not valid in this case. A line transect design was chosen to ensure that fishing stations would be chosen equidistant from the 200-mile boundary and to allow for statistical analysis of paired sets of data. Ten line transects approximately perpendicular to the 200mile boundary were chosen, spanning virtually the entire 200-mile boundary in Div. 3NO in depths from about 40 to $120 \mathrm{~m}$. From six to ten fishing stations (sets) were then chosen along each line, with the spacing of sets on each line being identical on both sides of the 200-mile boundary. All sets on a line were approximately 6 naut. miles apart, with the exception of the end stations on two lines which were 15 naut. miles from the next sets. The direction of fishing was kept constant for all sets on a given line and was generally parallel to the 200-mile boundary. Fishing was carried out on a continuous (24hour) basis where possible.

For each set, the following data were collected: mean fishing depth, numbers and weights of species caught, duration of tow, and a temperature profile of the water column, including the bottom, as measured by expendable bathythermograph. Catches from the few tows which were less than the prescribed 30-min. duration at a speed of 3.5 knots were multiplied to correspond to the norm. 

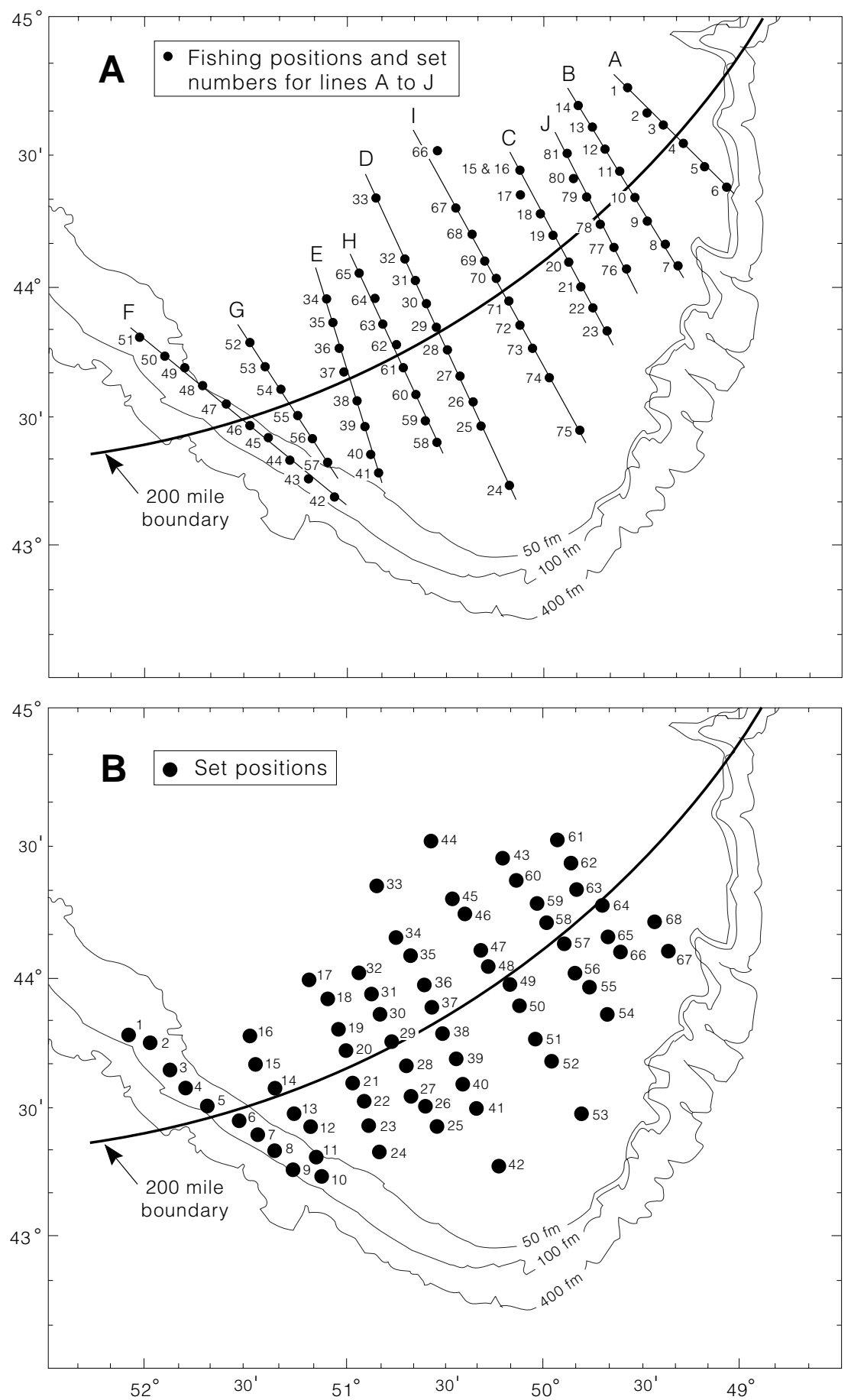

Fig. 2. Map of the survey area showing line transects surveys conducted by (A) R/V Wilfred Templeman in 1986 and (B) the Lady Hammond in 1987.

\section{Stratified-random surveys, 1971-89}

To examine the distribution of groundfish in the vicinity of the 200-mile boundary, data from stratified-random surveys in Div. 3NO were chosen. These surveys, based on the stratification scheme shown in Fig. 1, were designed to give annual estimates of the abundance and distribution of groundfish species, primarily cod and flatfish. The surveys were conducted in the spring of each year from 1971 to 1982 by the research vessel A. T. Cameron and from 1984 to 1989 by the research vessels Wilfred Templeman and Alfred Needler. There was no 
comparable survey in 1983. The former vessel was a side trawler which fished with a Yankee \# 41-5 otter trawl, while the other two vessels are identical stern trawlers which towed an Engels 145 otter trawl. The shaded area of Fig. 1 corresponds to the area of the line transect surveys. Valid sets in this area were chosen, the catches of American plaice, cod and yellowtail flounder were adjusted to the standard tow length where required, and each set was designated as being inside or outside the 200mile boundary.

Because the survey coverage (number of sets per stratum) in recent years (1984-89) was usually more intense than in earlier years, data for some analyses were grouped into 3-year periods to give adequate sample sizes. The data for 1984-89 were kept separate by year from most analyses, as this was the period of greatest interest in this study. Due to differences in the vessels and gears used, comparison of the mean number-and weight-per-tow for years after 1983 with the data for years prior to 1983 were not meaningful for all species (Gavaris and Brodie, MS 1984).

To test the data from the line transect and stratified-random surveys for normality, the ShapiroWilk test was used for sample sizes of 50 or less, and the Kolmogorov test was used for sample sizes greater than 50 (Conover, 1980). Given the difficulties in dealing with zero catches when transforming this type of data logarithmically, as well as the debate regarding statistically acceptable distribution of trawl survey data (e.g. Pennington, 1983), nonparametric statistics were used to test hypotheses concerning differences in catch levels. To compare catch levels inside versus outside the 200miles, both overall and line-by-line, the Wilcoxon rank-sum test (normal approximation, with continuity correction of 0.5) was used (Conover, 1980). The Wilcoxon matched - pairs signed - rank test ( $\mathrm{Hol}$ lander and Wolfe, 1973) was used to test for significant differences in paired observations on either side of the 200-mile boundary in the 1986 line transect survey. A pair of observations was taken as the catch weights from the two sets on a given line which were equidistant from the 200-mile boundary, and the statistical tests were then carried out by grouping the paired sets from all the transects. This analysis was not conducted on the data from 1987, as the survey was not complete in that year. All statistical tests were done using either SAS (SAS, 1985) or SPSS (Nie et al., 1975) computer package.

\section{Results \\ Line transect surveys, 1986 and 1987}

A total of 80 successful tows were completed in the 1986 survey compared with 66 in 1987. In 1987,
Line A was not surveyed and Line B was not completed, so these were eliminated form the analyses for that year. In both surveys, American plaice, cod and yellowtail flounder occurred regularly in the catches. For both years, the catch numbers and weights of all three species by location (inside 200miles versus outside) were found to differ significantly from a normal distribution at $P<0.01$ in all 24 cases (2 years, 3 species and 2 locations for each of the numbers and weights). These results are quite usual for trawl survey data (Brodie and Wells, MS 1985). The bottom temperatures measured in both surveys were quite different between lines and between years, but within each year the mean temperature on both sides of 200 miles were very similar.

In both 1986 and 1987 the catch weights-pertow of American plaice were higher for sets inside the 200 miles on most lines, while catch numbersper-tow were often greater outside 200 miles (Fig. 3). The mean weight-per-tow for all lines combined was significantly higher $(P<0.05)$ for sets inside 200 miles in both 1986 and 1987 (Table 1); the ratios of catch weights inside 200 miles to catch weights outside were 2.1 and 2.8 , respectively, in the two surveys.

In both years, yellowtail flounder were caught in most sets, with the exception of lines $F$ and $G$ which were in deeper water. Excluding these lines, eight of the nine sets in 1986 and all four of the sets in 1987 which contained no yellowtail flounder were outside 200 miles (Fig. 4). For most comparisons on the individual lines, particularly in 1987, catches were significantly higher both in numbers and weights from the sets inside 200 miles. The catches for all lines combined, both in numbers and weights, were also significantly higher $(P<0.05)$ for the sets inside 200 miles in 1986 and 1987 (Table 1), with the ratios of catch weights (inside to outside) being 4.2 and 9.5 , respectively.

Cod were not as widely distributed over the survey area as the flounder species, but like the flounders, most of the tows containing no cod occurred outside 200 miles in each year (Fig. 5). Cod catches were relatively small, and the largest catches (in numbers) consisted mainly of very small fish. As was the case for American plaice, few of the individual lines showed significant differences in the catches across the 200-mile boundary, although the totals for sets inside 200 miles were significantly higher $(P<0.05)$ for weights in both surveys, for numbers in 1986 ( $P<0.05)$, and for numbers in 1987 $(P<0.10)$ (Table 1$)$. The ratios of catch weights inside and outside 200 miles in 1986 and 1987 were 9.5 and 6.3 , respectively. 

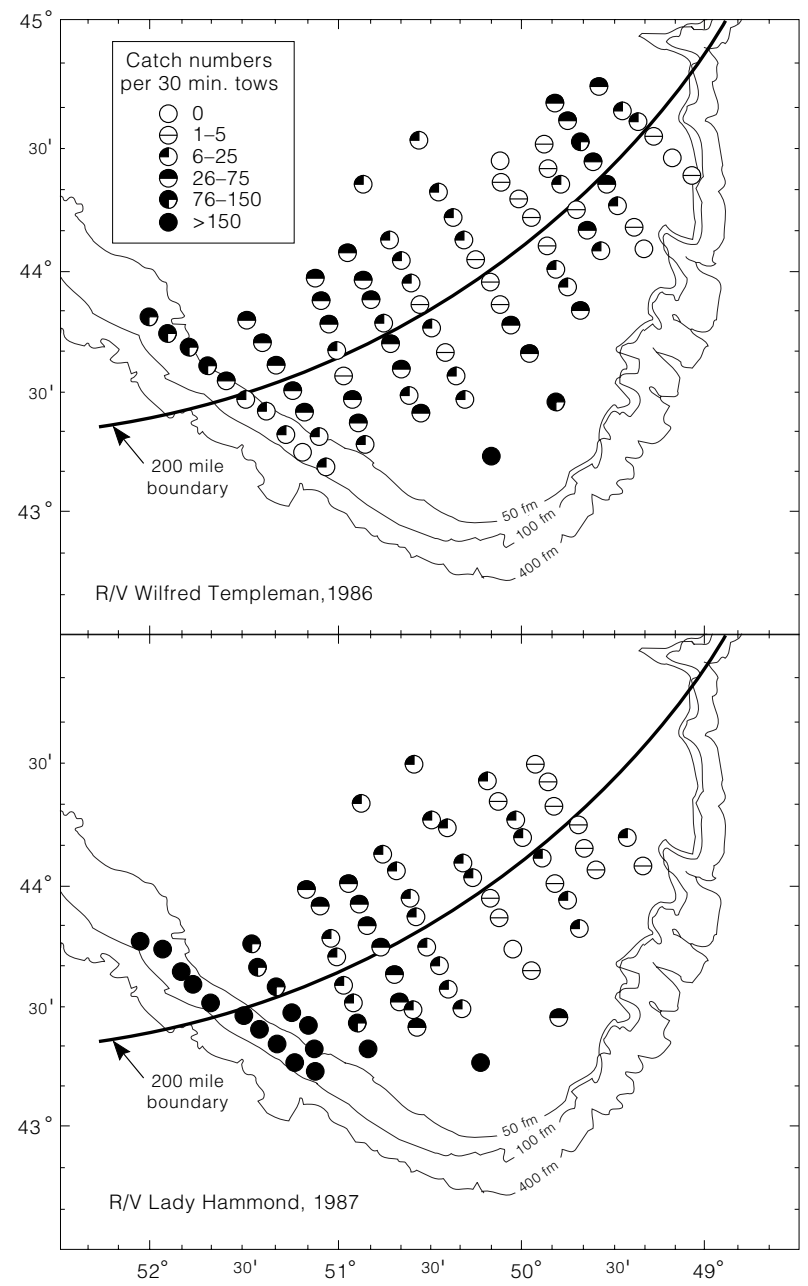

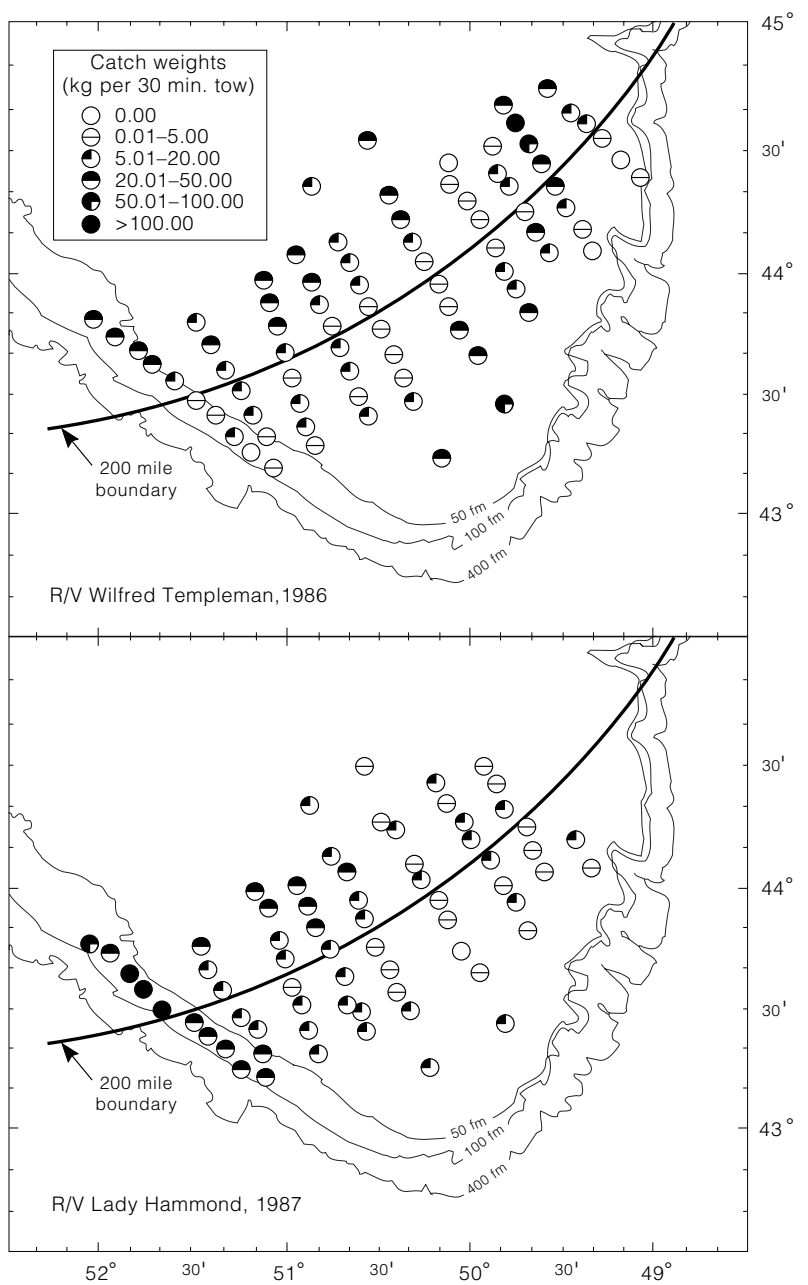

Fig. 3 Catches of American plaice in the line transect surveys of 1986 and 1987.

The Wilcoxon matched-pairs signed-ranks test showed that in 14 of the 15 cases, the number of positive ranks greatly exceeded the number of negative ranks, with a positive rank denoting larger catch weights inside versus outside the 200-mile boundary, and a negative rank denoting the converse (Table 2). For American plaice, the differences were significant at $P<0.05$ for the pairs of sets at the 15- and 21-mile intervals. For cod, the differences were significant $(P<0.05)$ for all groups except the one furthest from the 200-mile boundary, which was significant at $P<0.10$. In the case of yellowtail flounder, the sets at the 3-mile interval showed a significant difference at $\mathrm{P}<0.05$ while all the others were significant at $P<0.10$.

\section{Stratified-random surveys, 1971-82 and 1984-89}

A total of 404 sets was selected from the spring surveys for determination of trends in spatial distri- bution over time (Table 3). In almost all cases, the distribution of catch numbers and weights from these sets was significantly different from normal.

For American plaice, the mean numbers-pertow were greater from sets outside 200 miles for all periods except 1985, 1986 and 1987 (Fig. 6) and these differences were significant in 1974-76 and 1977-79 (Table 3). There was also a trend in the mean weights-per-tow, with catch weights outside 200 miles being greater than or equal to catches inside 200 miles in most of the period before 1983. However, after 1983, the opposite was true, with the results being statistically significant. The mean weights of individual American plaice in the survey catches was greater and more variable inside 200 miles, however, there was a general decline both inside and outside after 1983 with the pattern particularly apparent in the area outside 200 miles (Fig. $7)$. 

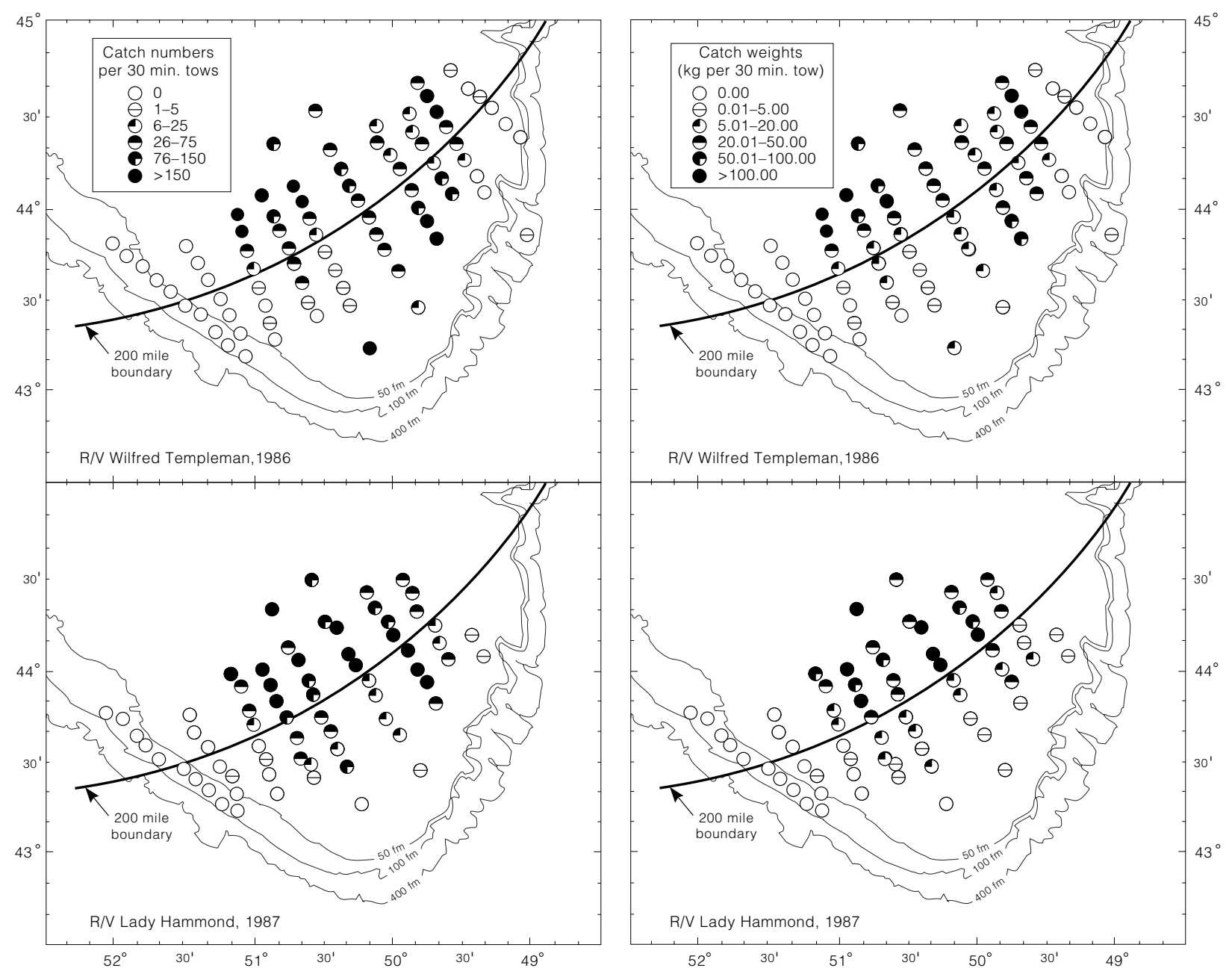

Fig. 4. Catches of yellowtail flounder in the line transect surveys of 1986 and 1987.

For yellowtail flounder, the mean numbers-pertow were greater for sets inside 200 miles in most of the time periods (Fig. 6). However, there were some periods (1980-82, 1985, 1989) when numbers were greater outside 200 miles. In all cases except 1985, mean weights-per-tow were greater inside 200 miles, being significantly so in four of the six time periods (Table 3). Severe declines in both mean numbersand weights-per-tow occurred from 1984 to 1986 in the area outside 200 miles. In 1989, there was a large increase in the mean numbers-per-tow outside 200 miles but only a modest increase in the mean weights-per-tow in this area. The mean weights-per-fish were relatively stable in both areas up to 1986, but after 1986 the mean fish weight outside 200 miles declined to a level less than half of the long-term average (Fig. 7). Although the mean weights-per-fish inside 200 miles also declined from 1986 to 1989, they remained within the range of previously observed values.
For cod, the mean numbers- and weights-pertow for sets inside 200 miles (Fig. 6) were significantly higher after 1976 (Table 3). Prior to 1980, the mean weights from sets inside 200 miles ranged from 10 to $22 \mathrm{~kg} /$ tow but increased to between 38 and $144 \mathrm{~kg} /$ tow thereafter. For sets outside 200 miles, the mean fluctuated between 3 and $19 \mathrm{~kg} / \mathrm{tow}$ after 1971, with no apparent trends. Prior to 1980, the mean weights of individual cod were roughly equal on either side of the 200-mile boundary (Fig. 7). However, in subsequent years, the mean weightper-fish was always greater from sets inside 200 miles, indicating a proportionately higher number of larger fish.

\section{Discussion}

The data for American plaice and yellowtail founder show that changes in abundance in relation to the 200-mile boundary have occurred in the mid- 
TABLE 1. Results (P values) of the Wilcoxon 2-sample test for numbers and weights of American plaice, cod and yellowtail flounder from the line transect surveys conducted in 1986 and 1987. The $P$ values are for one-tailed hypothesis tests $\left(H_{0}\right.$ : inside $>$ outside).

\begin{tabular}{|c|c|c|c|c|c|c|c|}
\hline \multirow[b]{2}{*}{ Line } & \multirow[b]{2}{*}{ Year } & \multicolumn{2}{|c|}{ American plaice } & \multicolumn{2}{|c|}{ Cod } & \multicolumn{2}{|c|}{ Yellowtail flounder } \\
\hline & & $\begin{array}{l}\text { No.- } \\
\text { per- } \\
\text { tow }\end{array}$ & $\begin{array}{c}\text { Weight- } \\
\text { per- } \\
\text { tow }\end{array}$ & $\begin{array}{l}\text { No.- } \\
\text { per- } \\
\text { tow }\end{array}$ & $\begin{array}{c}\text { Weight- } \\
\text { per- } \\
\text { tow }\end{array}$ & $\begin{array}{l}\text { No.- } \\
\text { per- } \\
\text { tow }\end{array}$ & $\begin{array}{l}\text { Weight- } \\
\text { per- } \\
\text { tow }\end{array}$ \\
\hline$A$ & 1986 & $.04^{*}$ & $.04^{*}$ & .10 & .10 & .10 & .10 \\
\hline B & 1986 & .06 & $.03^{*}$ & .12 & .15 & $.03^{*}$ & $.01^{*}$ \\
\hline $\mathrm{C}$ & $\begin{array}{l}1986 \\
1987\end{array}$ & $\begin{array}{l}.97 \\
.62\end{array}$ & $\begin{array}{l}.94 \\
.16\end{array}$ & $\begin{array}{l}.15 \\
.27\end{array}$ & $\begin{array}{c}.048^{*} \\
.18\end{array}$ & $\begin{array}{l}.94 \\
.77\end{array}$ & $\begin{array}{l}.90 \\
.03^{*}\end{array}$ \\
\hline $\mathrm{D}$ & $\begin{array}{l}1986 \\
1987\end{array}$ & $\begin{array}{l}.46 \\
.46\end{array}$ & $\begin{array}{l}.12 \\
.03^{*}\end{array}$ & $\begin{array}{l}.03^{*} \\
.46\end{array}$ & $\begin{array}{l}.07 \\
.27\end{array}$ & $\begin{array}{l}.01^{*} \\
.03^{*}\end{array}$ & $\begin{array}{l}.01^{*} \\
.01^{*}\end{array}$ \\
\hline$E$ & $\begin{array}{l}1986 \\
1987\end{array}$ & $\begin{array}{l}.06 \\
.77\end{array}$ & $\begin{array}{l}.06 \\
.16\end{array}$ & $\begin{array}{l}.33 \\
.33\end{array}$ & $\begin{array}{l}.16 \\
.16\end{array}$ & $\begin{array}{l}.01^{*} \\
.01^{*}\end{array}$ & $\begin{array}{l}.01^{*} \\
.01^{*}\end{array}$ \\
\hline $\mathrm{F}$ & $\begin{array}{l}1986 \\
1987\end{array}$ & $\begin{array}{l}.01^{*} \\
.20\end{array}$ & $\begin{array}{l}.01^{*} \\
.02^{*}\end{array}$ &. &. & - & - \\
\hline $\mathrm{G}$ & $\begin{array}{l}1986 \\
1987\end{array}$ & $\begin{array}{l}.04^{*} \\
.96\end{array}$ & $\begin{array}{l}.04^{*} \\
.50\end{array}$ & $\begin{array}{l}.40 \\
.50\end{array}$ & $\begin{array}{l}.50 \\
.75\end{array}$ & - & - \\
\hline $\mathrm{H}$ & $\begin{array}{l}1986 \\
1987\end{array}$ & $\begin{array}{l}.67 \\
.44\end{array}$ & $\begin{array}{l}.10 \\
.01^{*}\end{array}$ & $\begin{array}{l}.15 \\
.50\end{array}$ & $\begin{array}{l}.16 \\
.24\end{array}$ & $\begin{array}{l}.06 \\
.02^{*}\end{array}$ & $\begin{array}{l}.04^{*} \\
.03^{*}\end{array}$ \\
\hline I & $\begin{array}{l}1986 \\
1987\end{array}$ & $\begin{array}{l}.66 \\
.07\end{array}$ & $\begin{array}{l}.34 \\
.02^{*}\end{array}$ & $\begin{array}{l}.03^{*} \\
.10\end{array}$ & $\begin{array}{l}.01^{*} \\
.08\end{array}$ & $\begin{array}{l}.02^{*} \\
.01^{*}\end{array}$ & $\begin{array}{l}.01^{*} \\
.01^{*}\end{array}$ \\
\hline J & $\begin{array}{l}1986 \\
1987\end{array}$ & $\begin{array}{l}.87 \\
.50\end{array}$ & $\begin{array}{l}.81 \\
.33\end{array}$ & $\begin{array}{l}.04^{*} \\
.25\end{array}$ & $\begin{array}{l}.09 \\
.25\end{array}$ & $\begin{array}{l}.90 \\
.06\end{array}$ & $\begin{array}{l}.87 \\
.04^{*}\end{array}$ \\
\hline All & $\begin{array}{l}1986 \\
1987 \\
\end{array}$ & $\begin{array}{l}.07 \\
.49 \\
\end{array}$ & $\begin{array}{l}<.01^{*} \\
<.01^{*}\end{array}$ & $\begin{array}{c}<.01^{*} \\
.37 \\
\end{array}$ & $\begin{array}{c}<.01^{*} \\
.01^{*}\end{array}$ & $\begin{array}{l}<.01^{*} \\
<.01^{*}\end{array}$ & $\begin{array}{l}<.01^{*} \\
<.01^{*}\end{array}$ \\
\hline
\end{tabular}

to late-1980s. For cod, the changes coincided with the declaration of the 200-mile boundary in 1977. Prior to 1977, the fishery was not restricted by the 200-mile boundary and from 1977 to 1982, most non-Canadian fleets did not direct effort towards flatfish on the Tail of the Bank, as many continued to concentrate on the salt cod fishery. However, in the mid-1980s, many nations - notably Spain, Portugal and South Korea (NAFO, 1987) began fishing for groundfish with freezer trawlers, resulting in increased catches of flatfish and other species (Fig. 8).

The line transect data for 1986 and 1987 clearly showed that the abundance of American plaice, yellowtail flounder and cod was greater inside 200 miles than outside, with the differences often being significant over short distances. Also, the differences in catch-per-tow were obvious at all intervals along the line transects, as indicated by the paired- set comparisons done for the 1986 data. Overall, the differences were greater for weights-per-tow than numbers-per-tow, with cod and yellowtail flounder showing the largest discrepancies between catch weights inside and outside 200 miles. These data also indicated a proportionately lower number of large fish outside 200 miles compared to inside.

There were no observed physical factors which greatly affected the catch levels on either side of the 200-mile boundary in the line transect surveys. The operation of the fishing gear was kept constant, where possible, on both sides of the boundary. The line transects were designed so that the average fishing depths on both sides of the 200-mile boundary on each line would be approximately equal, and this objective was met in both 1986 and 1987. Diel variation in catches was not analyzed, and while this may have influenced catches, particularly yellowtail flounder (Walsh, MS 1986), on certain lines, 

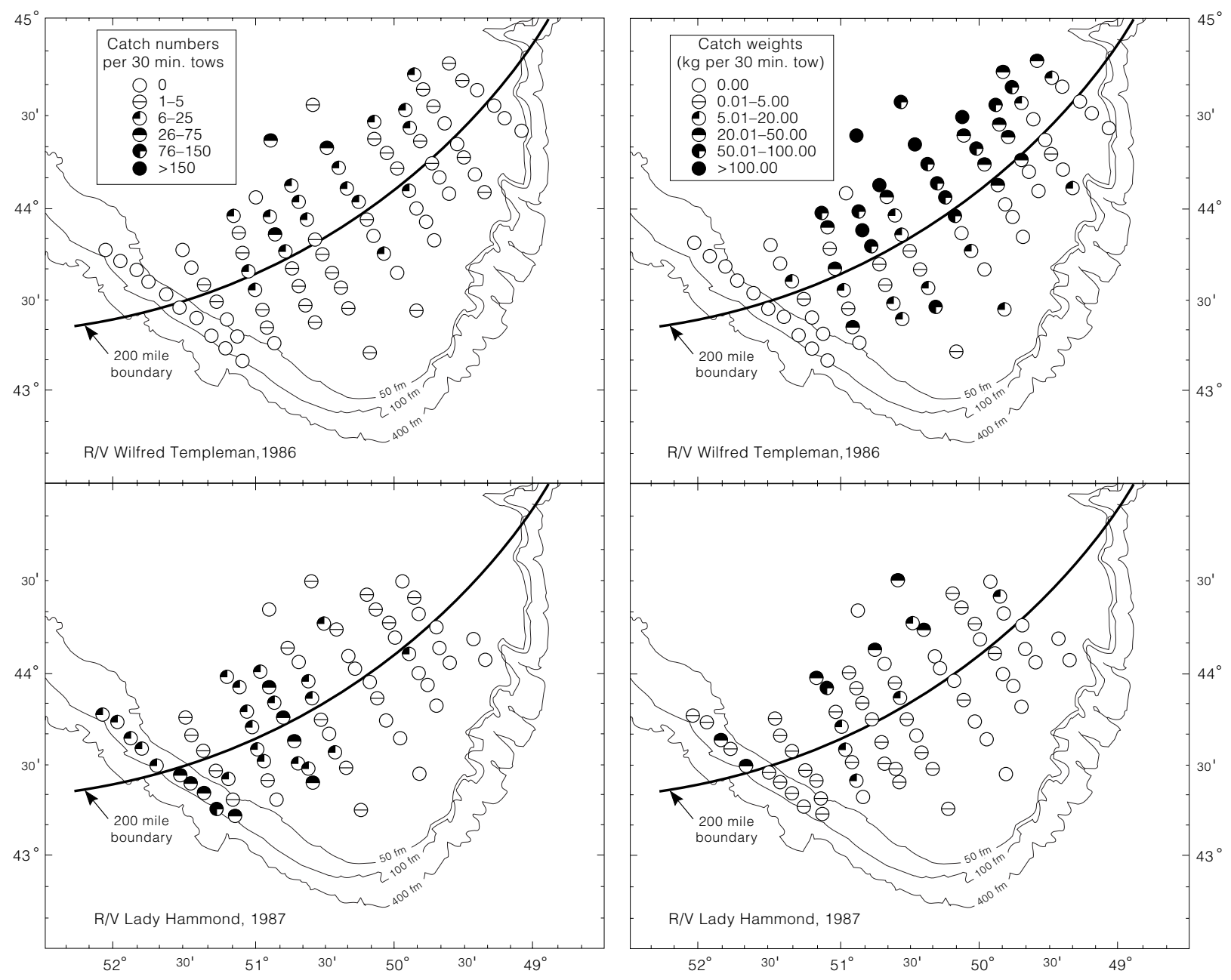

Fig. 5. Catches of cod in the line transect surveys of 1986 and 1987.

TABLE 2. Results of the Wilcoxon matched-pairs signed-ranks test for catch weights of American plaice, cod and yellowtail flounder from the 1986 line transect survey. The 3 values in each of the "Ranks" columns are the number of negative ranks (catch weight from set inside the 200-mile boundary is less than the corresponding catch weight outside), the number of positive ranks, and the number of ties respectively.

\begin{tabular}{|c|c|c|c|c|c|c|c|}
\hline \multirow{2}{*}{$\begin{array}{c}\text { Distance of } \\
\text { each set from } \\
\text { 200-mile boundary } \\
\text { (naut. miles) }\end{array}$} & \multirow{2}{*}{$\begin{array}{c}\text { No. of } \\
\text { pairs of } \\
\text { sets }\end{array}$} & \multicolumn{2}{|c|}{ American plaice } & \multicolumn{2}{|c|}{ Cod } & \multicolumn{2}{|c|}{ Yellowtail flounder } \\
\hline & & Ranks & P-value & Ranks & P-value & Ranks & P-value \\
\hline 3 & 10 & $3,7,0$ & .12 & $1,6,3$ & $.046^{*}$ & $1,7,2$ & $.01^{*}$ \\
\hline 9 & 10 & $2,8,0$ & .06 & $0,8,2$ & $.01^{*}$ & $2,5,3$ & .06 \\
\hline 15 & 10 & $2,8,0$ & $.02^{*}$ & $1,7,2$ & $.01^{*}$ & $2,6,2$ & .05 \\
\hline 21 & 7 & $1,6,0$ & $.046^{*}$ & $1,5,1$ & $.02^{*}$ & $1,5,1$ & .06 \\
\hline $\begin{array}{l}27 \\
36\end{array}$ & $\begin{array}{l}1 \\
2\end{array}$ & $2,1,0$ & .30 & $0,2,1$ & .09 & $0,2,1$ & .09 \\
\hline
\end{tabular}

* Significant at $\mathrm{P}<0.05$. 


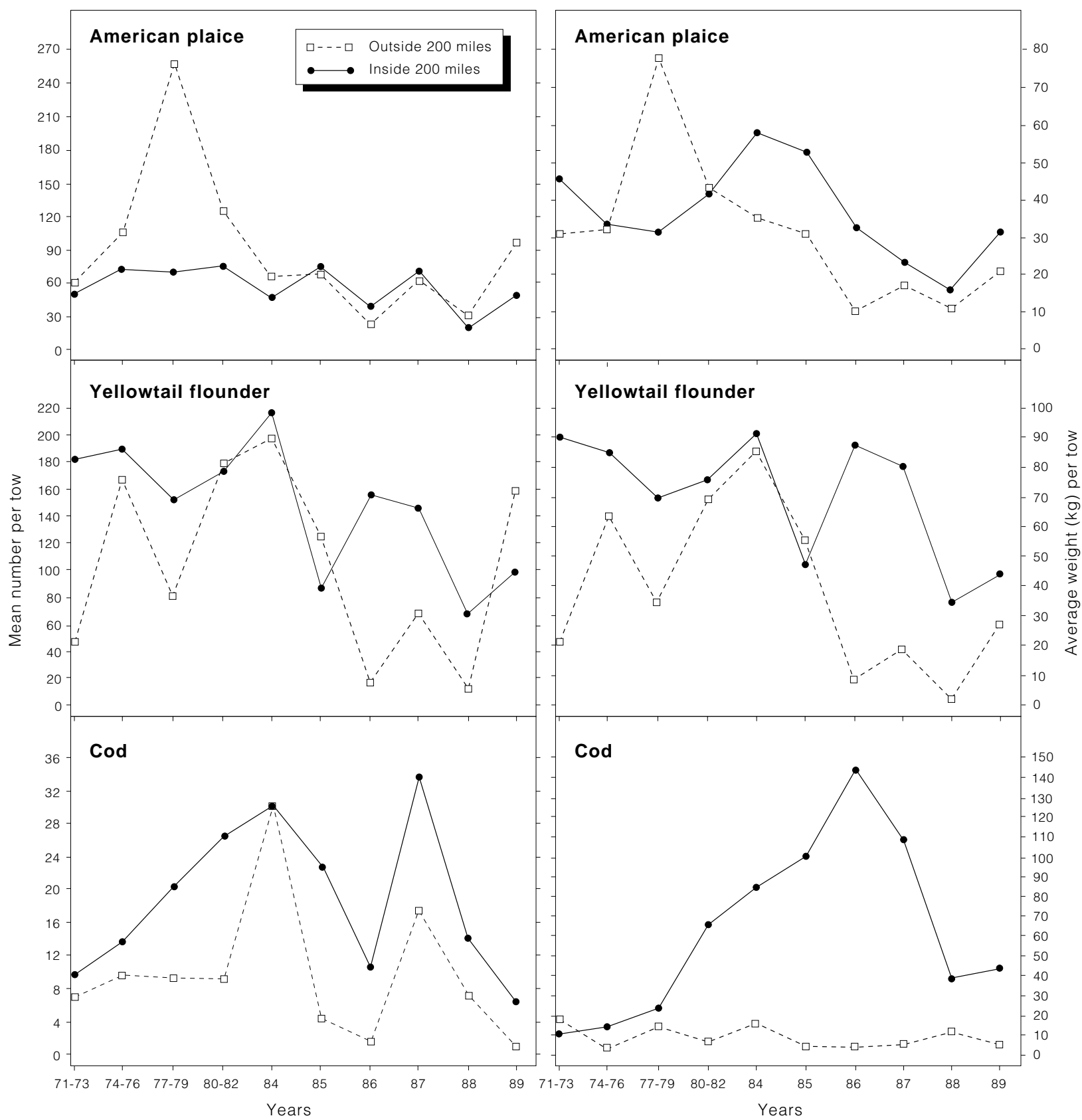

Fig. 6. Catches (numbers and weights) of American plaice, yellowtail flounder, and cod in the stratified-random surveys from 1971 to 1989.

the overall effect should be minimal because of the 24-hour sampling design of the surveys.

The comparison of the stratified-random survey data with the line transect survey results showed that the distribution (in relation to the 200-mile boundary) of American plaice, cod and yellowtail flounder observed in 1986 and 1987 was dissimilar to the distribution observed in earlier periods. For Ameri- can plaice, the declines in the catch numbers and weights outside 200 miles coincided with the changes in the fishery in the 1980s. The Canadian catch, which was taken largely inside 200 miles, decreased from a stable level of around 48000 tons in the late-1970s and early-1980s to around 35000 tons in 1983-86 (Fig. 8). The non-Canadian catch increased steadily from about 1000 tons in the late1970s to about 27000 tons in 1986, with these 


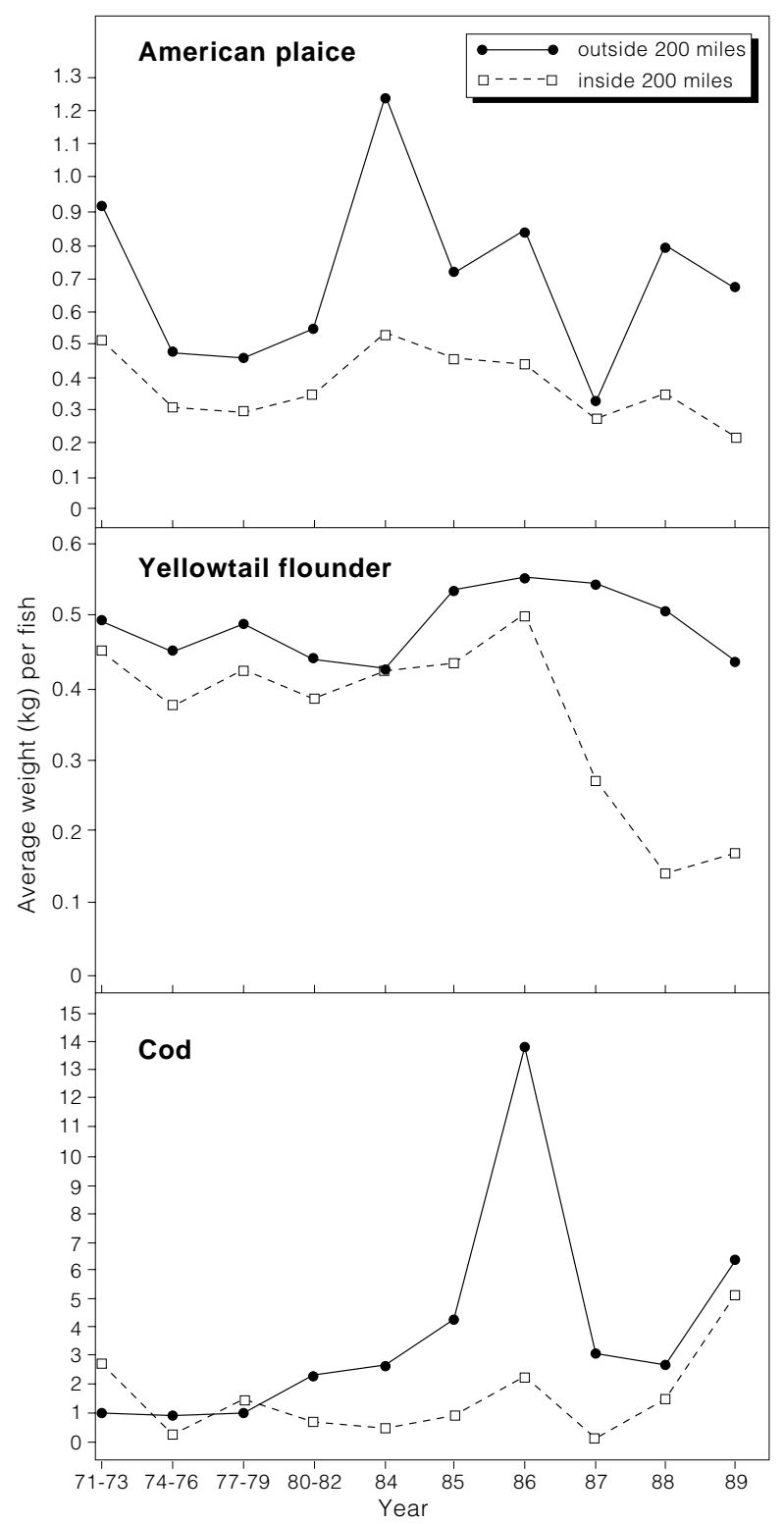

Fig. 7. Mean weights-per-fish of American plaice, yellowtail flounder, and cod in the stratified-random surveys from 1971 to 1989.

catches being confined to the areas outside 200 miles. Catches subsequently declined as the biomass of American plaice on the Tail of the Bank decreased (Brodie and Bowering, MS 1989).

The sharp increase in non-Canadian catches which occurred for the flatfish species in the mid1980s was not as prominent for cod. Catches rose gradually after about 1977, with a substantial increase from 1985 to 1986. There was little difference in the mean weights-per-tow of cod inside 200 miles versus outside in the 1971-79 period, but after 1979 the mean weights-per-tow inside 200

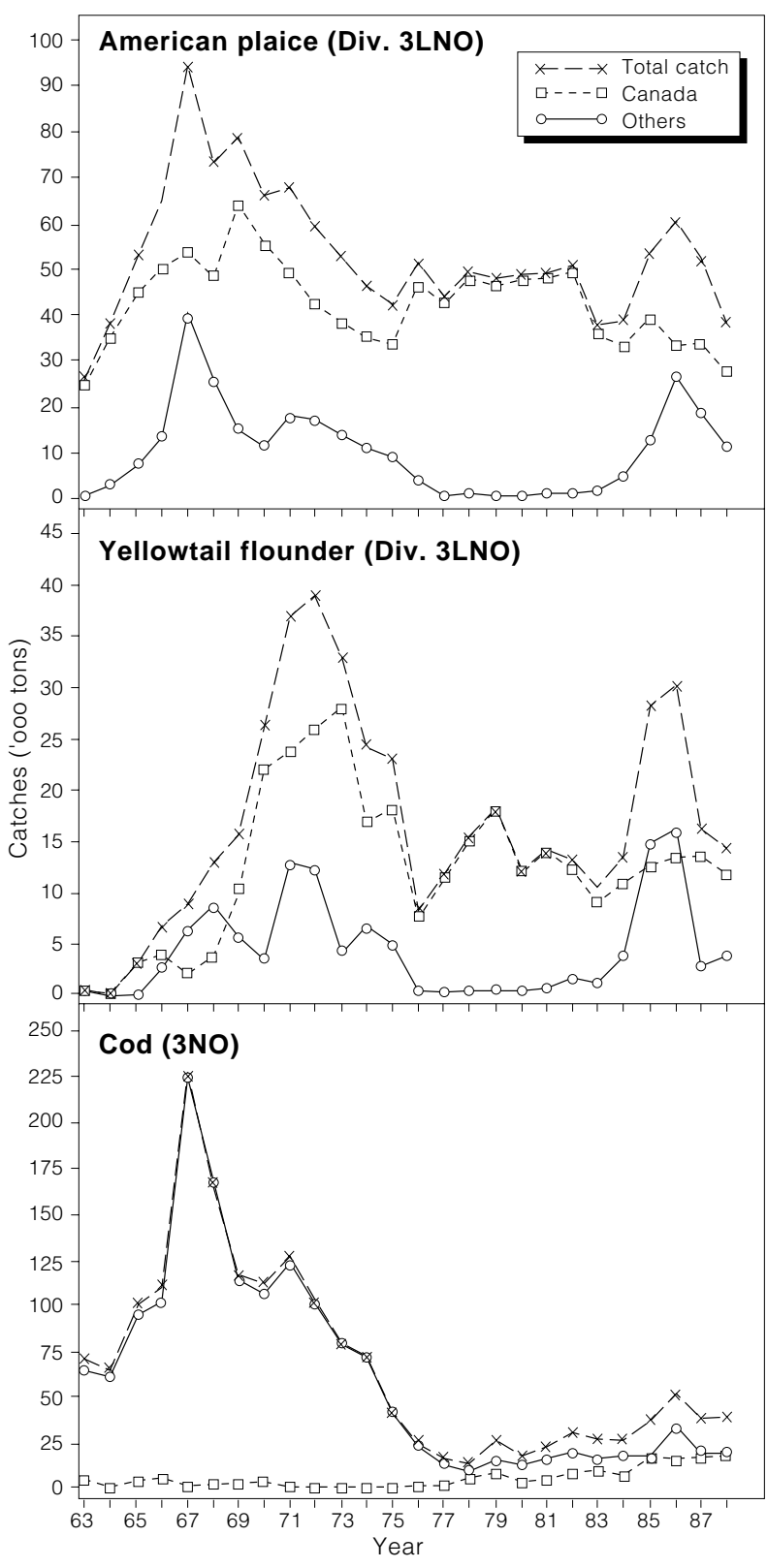

Fig. 8. Nominal catches of American plaice, yellowtail flounder, and cod from 1963 to 1988. The flatfish catches are for Div. 3LNO and cod catches are for Div. 3NO.

miles rose sharply and remained at a much higher level than the mean outside the 200-mile boundary. Baird and Bishop (MS 1989) indicated that the cod stock in Div. 3NO increased in biomass by about 4 times from 1976 to 1983-86, then deceased because of poor recruitment. That increase was reflected in the mean weights-per-tow from sets inside 200 miles where catches have been controlled since 1977, but not in the survey catches outside 200 miles, where the fishery has been less restricted. 
TABLE. 3. Results of the Wilcoxon 2-sample test for numbers and weights of American plaice, cod and yellowtail flounder from sets conducted during stratified-random surveys in the period 1971-89. N is the number of sets selected. Mean ranks, rather than rank sums, are shown because of the uneven sample sizes. The P-values listed are for two-tailed hypothesis tests, and underlined $\mathrm{P}$-values indicate cases where values for sets outside 200 miles were significantly higher than values inside 200 miles.

\begin{tabular}{|c|c|c|c|c|c|c|c|c|}
\hline \multirow[b]{2}{*}{$\begin{array}{c}\text { Time } \\
\text { period }\end{array}$} & \multirow[b]{2}{*}{$\begin{array}{l}\text { Position of } \\
\text { sets relative } \\
\text { to 200-mile } \\
\text { per-tow }\end{array}$} & \multicolumn{6}{|c|}{ Species } & \multirow[b]{2}{*}{$\begin{array}{l}\text { No. of sets } \\
\text { selected relative } \\
\text { to } 200 \text {-mile } \\
\text { boundary }\end{array}$} \\
\hline & & $\begin{array}{l}\text { America } \\
\text { Mean rank, } \\
\text { No.- } \\
\text { per-tow }\end{array}$ & $\begin{array}{l}\text { plaice } \\
\text { Mean rank, } \\
\text { Weight- } \\
\text { per-tow }\end{array}$ & $\begin{array}{c}\text { Co } \\
\text { Mean rank, } \\
\text { No. - } \\
\text { per-tow }\end{array}$ & $\begin{array}{l}\text { Mean rank, } \\
\text { Weight- } \\
\text { per-tow }\end{array}$ & $\begin{array}{c}\text { Yellowtail } \\
\text { Mean rank, } \\
\text { No.- } \\
\text { per-tow }\end{array}$ & $\begin{array}{l}\text { Ounder } \\
\text { Mean rank } \\
\text { Weight- } \\
\text { limit }\end{array}$ & \\
\hline & inside & 16.6 & 17.1 & 14.5 & 14.4 & 18.5 & 18.8 & 16 \\
\hline 1971-73 & outside & 13.0 & 12.4 & 15.6 & 15.8 & 10.7 & 10.4 & 13 \\
\hline & $P$ value & .27 & .15 & .74 & .68 & $.01^{*}$ & $<.01^{\star}$ & \\
\hline & inside & 15.9 & 17.9 & 18.8 & 20.3 & 20.2 & 20.0 & 23 \\
\hline 1974-76 & outside & 23.2 & 19.5 & 18.0 & 15.4 & 15.4 & 15.8 & 13 \\
\hline & $P$ value & $.048^{*}$ & .68 & .83 & .19 & .19 & .26 & \\
\hline & inside & 26.7 & 27.6 & 36.8 & 37.3 & 37.5 & 37.9 & 37 \\
\hline 1977-79 & outside & 41.3 & 40.2 & 28.0 & 27.4 & 27.1 & 26.6 & 28 \\
\hline & $P$ value & $\leq .01^{*}$ & $\leq .01^{*}$ & .06 & $.04^{*}$ & $.03^{*}$ & $.02^{\star}$ & \\
\hline & inside & 31.3 & 34.7 & 44.2 & 45.2 & 35.8 & 38.1 & 32 \\
\hline 1980-82 & outside & 39.1 & 36.2 & 28.1 & 27.3 & 35.3 & 33.3 & 38 \\
\hline & $\mathrm{P}$ value & .11 & .75 & $<.01^{\star}$ & $<.01^{\star}$ & .92 & .33 & \\
\hline & inside & 56.5 & 67.3 & 70.4 & 75.5 & 62.4 & 63.5 & 47 \\
\hline 1984-86 & outside & 52.1 & 43.6 & 41.2 & 37.2 & 47.5 & 46.5 & 60 \\
\hline & $P$ value & .47 & $<.01^{*}$ & $<.01^{*}$ & $<.01^{*}$ & $.01^{*}$ & $<.01^{*}$ & \\
\hline & inside & 45.8 & 61.0 & 62.8 & 66.9 & 61.2 & 64.6 & 38 \\
\hline 1987-89 & outside & 51.1 & 41.3 & 40.1 & 37.5 & 41.2 & 38.9 & 59 \\
\hline & $P$ value & .37 & $<.01^{\star}$ & $<.01^{*}$ & $<.01^{\star}$ & $<.01^{*}$ & $<.01^{*}$ & \\
\hline
\end{tabular}

* Significant at $P<0.05$.

Yellowtail flounder is perhaps the best sample of the three species considered for which abundance in relation to the 200-mile boundary was affected by the fishery in the 1980s on the Tail of the Bank. Of the three stocks examined, yellowtail flounder has the most localized distribution, primarily in and around the Southeast Shoal area (strata 375 and 376, Fig. 1) in Div. 3N (Pitt, 1970), and has had a relatively high percentage, on average, of stock biomass located outside 200 miles (Brodie, MS 1986).

It is apparent, both from the line transect surveys of 1986 and 1987 and the stratified-random surveys in the same years, that yellowtail flounder was about 5-10 times more abundant inside 200 miles than outside. However, the stratified-random surveys clearly indicate that this was not always so. Following the large catches outside 200 miles in 1985 and 1986, the abundance in this area decreased to very low levels relative to the area inside 200 miles, where catches had remained relatively stable, and where the decrease in abundance was not as severe. Brodie and Walsh (MS 1988) showed that yellowtail flounder biomass outside 200 miles in Div. $3 \mathrm{~N}$ declined further than the biomass in the remainder of Div. 3N over the period 1984-88. The increase in the mean numbers-per-tow outside 200 miles in 1989 was mainly a result of the large 1985 year-class becoming available to the survey gear (Brodie et al., MS 1989). The survey catches in 1989 were comprised of young fish as seen by the smaller increase in mean weights-per-tow in that year compared to the larger increase in mean numbers-per-tow.

The trends in weight per yellowtail flounder caught in the areas on each side of the 200-mile boundary can also be explained by the increased catches outside 200 miles. The fact that yellowtail flounder were smaller on average in the area outside 200 miles is not surprising, given that the majority of juvenile yellowtail flounder in this stock are found in the area just outside the 200-mile boundary (Walsh, MS 1989). However, the decline in mean fish weight outside 200 miles was not caused by a large increase in the number of small yellowtail flounder in the area. Rather, it was caused by a decrease in the abundance of larger yellowtail flounder, most notably the strong 1978 and 1979 year-classes, which were fished heavily in the area outside 200 miles in 1985 and 1986, and were followed by three relatively poor year-classes (Brodie and Walsh, MS 1988). This decline in mean fish weight has also shown up in the commercial fisheries outside 200 miles (Brodie et al., MS 1989). 
The assessments of the stocks examined here indicate substantial declines in abundance in recent years for all three species (NAFO, 1989). It is evident from the survey data that the trends in abundance were different on either side of the 200mile boundary. For the flatfish stocks, the declines in abundance were more severe outside 200 miles and coincided with rapidly increasing catches. For cod, the abundance outside 200 miles remained relatively low throughout the 1970s and 1980s while the abundance inside increased substantially after the 200-mile boundary was declared.

There are, of course, many biological and physical influences which could affect catches of groundfish species in the Tail of the Bank area. For example, it is well known that the spatial distribution of cod is greatly affected by spawning and feeding migrations (Templeman, 1974). On the other hand, the two flatfish species are somewhat sedentary (Pitt, 1969), and it is generally accepted that neither form major pre-spawning or spawning concentrations on the Grand Bank (Pitt, 1966). Although the mid-1980s saw a period of very low bottom temperatures over much of the Grand Bank (Wells et al., MS 1988), it is unlikely that this event, or any other physical factor, could produce localized effects which would cause the changes in abundance presented here. Recognizing the natural differences in the biology, habitat and distribution of these three species, it would be virtually impossible for physical or environmental factors to act in a manner that would greatly influence the survey catches of all three species over such a relatively small distance, i.e. a few miles on either side of the 200-mile boundary. Analyses of factors such as juvenile abundance, growth rates, migration patterns, and the physical environment should form the focus of further work on the effects of exploitation on the abundance of groundfish in the Tail of the Grand Bank area.

\section{Acknowledgements}

I thank the technical staff who collected and processed the research vessel data, and C. Butt, who drafted the figures. Various members of the scientific staff, particularly W. R. Bowering, assisted in the line transect survey design and provided suggestions which were helpful in the preparation of the manuscript. I also thank J. Baird and $P$. Pepin, as well as an anonymous reviewer, for their reviews of an earlier draft of this manuscript.

\section{References}

BAIRD, J. W., and C. A. BISHOP. MS 1989. An assessment of the cod stock in NAFO Div. 3NO. NAFO SCR Doc., No. 35, Serial No. N1611, 61 p.

BRODIE, W. B. MS 1986. An assessment of yellowtail flounder in NAFO Div. 3LNO. NAFO SCR Doc., No. 40, Serial No. N1156, $20 \mathrm{p}$.

BRODIE, W. B., and W. R. BOWERING. MS 1989. An assessment update for the American plaice stock in Divisions 3LNO. NAFO SCR Doc., No. 37, Serial No. N1614, $62 \mathrm{p}$.

BRODIE, W. B., and S. J. WALSH. MS 1988. An update on the status of the yellowtail flounder stock in Divisions 3LNO. NAFO SCR Doc., No. 38, Serial No. N1478, 42 $\mathrm{p}$.

BRODIE, W. B., S. J. WALSH, and W. R. BOWERING. MS 1989. An assessment of the yellowtail flounder stock in Divisions 3LNO. NAFO SCR Doc., No. 68, Serial No. N1648, p.

BRODIE, W. B., and R. WELLS. MS 1985. The distribution of trawl catches of cod and American plaice from research vessel surveys in NAFO Divisions $3 \mathrm{~L}, 3 \mathrm{M}$ and 3 N. NAFO SCR Doc., No. 106, Serial No. N1082, $14 \mathrm{p}$.

CONOVER, W. J. 1980. Practical nonparametric statistics. John Wiley and Sons Inc., New York.

GAVARIS, S., and W. B. BRODIE. MS 1984. Results of comparative fishing between the A. T. Cameron and Wilfred Templeman during July-August 1983. CAFSAC Res. Doc., No. 41, 16 p.

HOLLANDER, M., and D. A. WOLFE. 1973. Nonparametric Statistical Methods. John Wiley and Sons Inc., New York.

ICNAF. 1972-78. Fishery Statistics. ICNAF Stat. Bull., Vol. 22-28 (rev.)

NAFO. 1984. Fishery Statistics. NAFO Stat. Bull., Vol. 29 (rev.) and 30 (rev.).

1987. Scientific Council Reports, 1987. NAFO Sci. Coun. Rep., 1987, 138 p.

1989. Scientific Council Reports, 1989. NAFO Sci. Coun. Rep., 1989, 180 p.

NIE, N. H., C. H. HULL, J. G. JENKINS, K. STEINBRENNER, and D. H. BENT. 1975. SPSS-Statistical Package for the Social Sciences, Second edition. McGraw Hill, New York.

PENNINGTON, M. 1983. Efficient estimators of abundance for fish and plankton surveys. Biometrics, $\mathbf{3 9}$ : 281-286.

PITT, T. K. 1966. Sexual maturity and spawning of the American plaice, Hippoglossoides platessoides (Fabricius), from Newfoundland and Grand Bank areas. J. Fish. Res. Board Can., 23: 651-672.

1969. Migrations of American plaice on the Grand Bank and in St. Mary's Bay, 1954, 1959, and 1961. J. Fish. Res. Board Can., 26: 1301-1319.

1970. Distribution, abundance, and spawning of yellowtail flounder, Limanda ferruginea, in the Newfoundland area of the Northwest Atlantic. J. Fish. Res. Board Can., 27: 2261-2271.

SAS Institute Inc. 1985. SAS User's Guide: Statistics, Version 5 Edition. Cary, N.C.

TEMPLEMAN, W. 1974. Migrations and intermingling of Atlantic cod (Gadus morhua) stocks of the Newfoundland area. J. Fish. Res. Board Can., 31: 1073-1092.

WALSH, S. J. MS 1986. Juvenile yellowtail surveys on the Grand Banks. NAFO SCR Doc., No. 39, Serial No. N1153, $15 \mathrm{p}$.

MS 1989. Distribution of juvenile American plaice on the Grand Bank, NAFO Divisions 3LNO. NAFO SCR Doc., No. 71, Serial No. N1651, 15 p.

WELLS, R., W. B. BRODIE, C. A. BISHOP, and J. W. BAIRD. MS 1988. Distribution and abundance of three fish species on the Grand Bank in relation to depth and temperature of the water. NAFO SCRDoc., No. 94, Serial No. N1546, 26 p. 